I was left with some unease after my first reading - not so much with the content of some of these essays, but more with some of their assumptions. Some papers would have benefited from more expansive treatment; one can look forward to more voluminous publications by writers such as Olwage and Gilbert. All this said, this book rightfully claims to be the "first of its kind" (ii) to deal with these diverse and complex issues within a South African context. It is a worthwhile read full of interesting insights and ideas that promises to provide rich ground for further research and argument.

Franklin Larey

University of Cape Town, Cape Town

\section{Every step of the way. The journey to freedom in South Africa.}

Michael Morris. Cape Town: HSRC Press. 2004. 344 pp. ISBN 0796920613.

Michael Morris, a journalist, wrote Every step of the way, with the advice of Bill Nasson, a well-respected historian from the University of Cape Town. One of the stated objectives of the author is to contribute to a space that became available in post-apartheid South African education. There is namely a shortage of (school) history textbooks written from a post-apartheid mindset or frame of reference.

Although the author engages the usual chronology (with the well-known turning points: 1910, 1948, 1960, 1990 and 1994) he intends to write the history of his country in an interesting and different way, a participative one. He uses poetry, songs, book and newspaper extracts, drawings as well as white and black pictures to illustrate the text. These additional forms of information complement the written text and create an interesting whole. However, it is a pity that historical maps are not included, since these are normally quite useful in books of this kind.

The central idea of the book is that all the inhabitants contributed to the creation of the country's history and that South Africans should recognise one another's contribution. Morris writes from an optimistic point of view without necessarily privileging well-known historical characters, be they black or white, woman or male, or without denying the country's racial problems.

For instance, approaching the major processes that shaped the country the author pays attention to the usual big personalities and politicians but he also draws attention to the ways in which ordinary South Africans contributed. It becomes a way of reaching beyond the individual to the participation of everyone in the country's achievements and failures. For example, he writes about a South African family, like the Verwoerds, who are supporters and opponents of the apartheid regime (chapter 9); while a special space is dedicated to women's contribution to the history of the country (chapter 10). The book's obvious intention is to bridge the country's diversity and its internal divisions. In reading it, one is reminded of the spirit of the Freedom Charter: "South Africa belongs to all who live in it, black and white".

Although the book is not intended as an academic text, it approaches certain theoretical problems in the writing of history, for example: do individuals make history or does history make the individual? In the same manner, it presents some of the problems and debates central to South African historiography. A case in point is the discussion of the Mfecane. Here Morris presents cogently the different positions historians took on this matter and the making 
of states in the region in the $18^{\text {th }}$ and $19^{\text {th }}$ centuries.

More than half of the book is devoted to the $20^{\text {th }}$ century. Each chapter is written in such a way that the topic is developed up to the present. The chapter on gold is a case in point. It starts out with the discovery of gold and is taken through to the formation of the trade unions in the 1980s, the role of its leaders in the anti-apartheid struggle, the transition period and up to the first years of democracy.

It is an ambitious book. In more than 300 pages, Morris seeks to present South African history from the first appearance of humans on earth until the present. Although the Department of Education commissioned and funded the book to commemorate ten years of the democracy, it is neither laudatory of the present government nor does it indulge its leaders. Indeed, the writer, at times is critical of the present government and the book is fortunately not an "official history".

The author's writing is appealing and this makes for engaging reading. Readers with some degree of education will find the book accessible and easy to read. They will find information not only about their national history (the bibliography is useful, appropriate and up to date) but also new interpretations of well-known events. One of the best things of the book is that does not pretend to be the last word in history, as so often happens in books of this type. The author prefers to question rather than to provide ultimate and final answers.

For me, as a historian in Argentina, the book presents some interesting lessons. In my country, at the national as well as the provincial levels similar educational processes are under way: the encouragement of new textbooks and popular history books. Although these texts introduce indigenous people's history (much of which is currently denied, undervalued or hidden) much more needs to be done. For instance, we still fail to recognise the participation of black people in our history, so that the perception persists (shared by locals and foreigners) that Argentina is a "white country". In my context, Morris's book points to a direction that may be useful to emulate.

Every step of the way is an important contribution to the writing of history - a history that is still in progress. As Prof. Kader Asmal in his foreword suggests, the book is an important attempt to revitalize the study of South African history. It generates doubts and queries about the present and the past (something that historians and social scientists in general should pursue).

\section{Marisa Pineau \\ Universidad de Buenos Aires, Universidad Nacional de Quilmes, Argentina}

The HSRC Press is an open access publisher; the entire text of Every step of the way. The journey to freedom in South Africa may be downloaded from the HSRC website, www. hsrc.ac.za [eds.].

\section{Ek ken jou goed genoeg ... Die brief- wisseling tussen N.P. van Wyk Louw en W.E.G Louw 1936-1939.}

J.C. Kannemeyer en andere (reds). Pretoria: Protea Boekhuis. 2004. 309 pp. ISBN 1-86919-088-2.

Tussen die jare 1936-1939 toe N.P. van Wyk Louw in Kaapstad gewoon het en in diens van die Universiteit van Kaapstad as lektor in die filosofie van die onderwys was, was sy broer, W.E.G Louw, in Nederland besig met sy doktorale studie in die letterkunde.

Hierdie boek is die eerste noukeurige, wetenskaplike, uitgawe van briewe op die gebied van die Afrikaanse letterkunde. Dit 